\title{
INFLUENCE OF THE GEOMETRICAL RESEARCHES OF RARE TYPE SURFACES ON DESIGN OF NEW AND UNIQUE STRUCTURES
}

\author{
MAMIEVA I.A. ${ }^{1}$, GBAGUIDI-AISSE G.L. ${ }^{2}$ \\ ${ }^{1}$ Peoples' Friendship University of Russia (RUDN University), Moscow, Russia \\ ${ }^{2}$ Laboratoire d'énergétique et de mécanique appliquées (LEMA) Ecole Polytechnique d'Abomey-Calavi, Univ. \\ d'Abomey-Calavi BP 2009 Cotonou, République du Bénin
}

\begin{abstract}
The aim of the paper is to illustrate using of analytical surfaces, i.e. surfaces, which can be given by vector, parametric or explicit equations, in real structures, i.e. in parametric architecture. Parametric architecture is a unique style in which such concepts as sculpture, mathematics, structural mechanics, and architecture are interconnected. Parametric design in contrast to other styles has a relationship with mathematics. This paper continues a series of works of the authors devoted to application of analytical surfaces in architecture and building, devoted to investigation of influence of researches on the geometry of surfaces on design of large-span shell structures and to application of interesting geometrical forms for unique erections. In the paper, a photo of only one erection having this form illustrates every analytical surface, which can be seen in forms of real erections. It turned out that only 42 of the 600 surfaces described in the literature were used in the World. For those who are interested in the mathematical side of design of surfaces, their computer modeling, or more detailed information about real structures in the form of the surfaces in question, a voluminous bibliography are given.
\end{abstract}

Keywords: parametric architecture, surface geometry, forming surfaces, surface classification, shell, shell structure; public, residential, and industrial buildings.

\section{ВЛИЯНИЕ ГЕОМЕТРИЧЕСКИХ ИССЛЕДОВАНИЙ РЕДКИХ ТИПОВ ПОВЕРХНОСТЕЙ НА СОЗДАНИЕ НОВЫХ И УНИКАЛЬНЫХ СООРУЖЕНИЙ}

\author{
МАМИЕВА И.А. ${ }^{1}$, ГБАГУИДИ АЙССЕ Ж.Л. ${ }^{2}$ \\ ${ }^{1}$ Российский университет дружбы народов, Москва, Российская Федерация \\ ${ }^{2}$ Университет Абомей-Калави, 02 ВР 244 Котону, Республика Бенин
}

\begin{abstract}
Аннотация. Цель статьи - анализ использования аналитических поверхностей, то есть поверхностей, которые могут быть заданы векторными, параметрическими или неявньми уравнениями, в реальных конструкииях, то есть в параметрической архитектуре. параметрическая архитектура - это уникальный стиль, который объединяет скульптуру, математику, строительную механику и архитектуру. Параметрическое проектирование в отличие от других стилей имеет тесную связь с математикой. Статья является продолжением серии работ авторов, посвященных применению аналитических поверхностей в архитектуре и строительстве, а также исследованию влияния исследований по геометрии поверхностей на проектирование большепролетных структур и применению интересных геометрических форм для уникальных сооружений. В статье каждая аналитическая поверхность, которую можно увидеть 8 формах реальных сооружений, иллюстрируется фотографией только одного сооружения, имеющего эту форму. Обнаружено, что только 42 из 600 поверхностей, описанные в научнотехнической литературе, были использованы в мировой практике. Для тех, кто интересуется математической стороной проектирования аналитических поверхностей, их компьютерным моделированием, или более подробными сведениями о реальных сооружениях в форме рассматриваемых поверхностей приведена обширная библиография.
\end{abstract}

Ключевые слова: параметрическая литература, геометрия поверхностей, формообразование поверхностей, классификация поверхностей, оболочка, оболочечная структура, промышиленные и гражданские здания. 


\section{Introduction}

Nowadays there are known more than 600 analytical surfaces set by the explicit, implicit, vector or parametrical equations [1] that are grouped in 38 classes. There are several options of classifications of analytical surfaces; the fullest of them is presented in a work [2]. In some works, for example in [3 - 5], attempts to find out the most popular analytical surfaces among architects which were used for design of public, residential, and industrial buildings were made. This style is called the parametrical architecture [6,7]. The present manuscript continues the researches begun by the authors in the works [3, 5, $8-11]$ in which the known thin-walled shell erections realized in practice or erections in design of which the most prominent architects took part, or the structurers having the most optimum technical-and-economic parameters, or the structures noted by prizes and taking high places in various ratings of professional associations and magazines are presented. Now, only rare classes of analytical surfaces embodied in real thin-walled shell structures will be considered.

\section{Method of researches}

In a paper, methods of researches assumed in analytical and differential geometry of surfaces will be used and applied for study of middle surfaces of thin-walled shell structures. Every analytical surface will be illustrated with one erection outlined on the corresponding surface. The presented manuscript is the final stage of common researches of the authors devoted to the study of influence of geometrical investigations of analytical surfaces on design of unique structures and buildings. Broadening of possibilities of computer modelling for shape finding methods of shells with attraction of differential geometry with consequent automatic using of numerical methods of analysis is the aim of the paper. For this aim, it is necessary to research the degree of drawing analytic surfaces into the practice of design of thin-walled shell structures.

\section{Results of the research}

Let us examine classes, subclasses, and groups of rare analytical surfaces that found the application in the shapes of public, residential, and industrial buildings. Ruled, translation surfaces, and surfaces of revolution were studied in other works of the authors [3, 11].

\subsection{Helical surfaces}

A helical surface is formed by a curve in the process of its helical motion. The generatrix curve uniformly revolves on an axis of revolution and at the same time executes a translational motion in the direction of the same axis. If the ratio of a value of the speed along the straight line to a value of the angular velocity is constant then a helical motion is called an ordinary helical motion.

\subsubsection{Ordinary helical surfaces}

A surface formed by ordinary helical motion is called an ordinary helical surface. This type of helical surfaces includes right helicoids and cylindrical helical strips and pseudo-developable helicoids.

\subsubsection{Pseudo-developable helicoid}

At the beginning of the 21st century, architects and mechanical engineers paid attention to the box surfaces on the basis of a circular cylinder $[12,13]$. In many large cities, skyscrapers are built in the form of a twisted rod of rectangular cross-section. The Infinity Tower, $306 \mathrm{~m}$ high with a 90-degree turn relative to the base, was built in the prestigious Dubai Marina district in the United Arab Emirates (Fig. 1). There are other objects that have this form. In all cases, a box-shaped surface on the basis of the circular cylinder is composed of $n$ identical intersecting along helical lines pseudo-developable helicoids and cross-sections represent a regular polygon with $n$ sides. 


\subsubsection{Circular helical surfaces}

A circular helical surface is obtained by the ordinary helical motion of a freely located generatrix circle of a constant radius. Circular helical surfaces are also included in the class of cyclic surfaces. According to the position of a directrix circle, circular helical surfaces are divided into 4 groups. Only 2 groups are used in the architecture: a tubular helical surface and a right circular helical surface.

\section{Tubular helical surface}

Tubular helical surfaces are used in the design of solid and hollow helical springs, in round section coils or to give the column the shape of a helical pole.

Right circular helical surface

This surface is formed by the ordinary helical motion of a circle of constant radius located in a plane perpendicular to the helical axis [1]. A surface of helical pole is a variety of the right circular helical surface. In Fig. 2, the surfaces of the helical poles have four directrix circles similar to poles of Iglesia Santa Maria Magdalena, Olivenza, Spain (the XVI ${ }^{\text {th }}$ century).

\subsubsection{Helical surfaces with arbitrary plane generatrix curves}

A helical surface with an arbitrary plane generatrix curve (helicoid of general type) is formed by some profile rotating about an axis and at the same time executing a translation motion along the same axis. In addition, the translational speed of the profile is proportional to its angular velocity. These surfaces can give modern architects good tool for creativity. Almost any city has playgrounds with children slides in the form of this surface (Fig. 3).

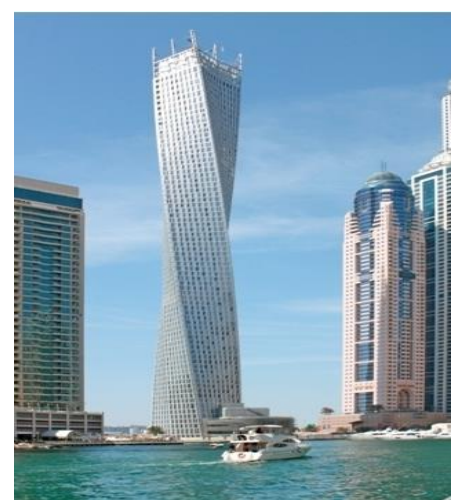

Figure 1 - Infinity Tower. Each side of it is a pseudo-developable helicoid

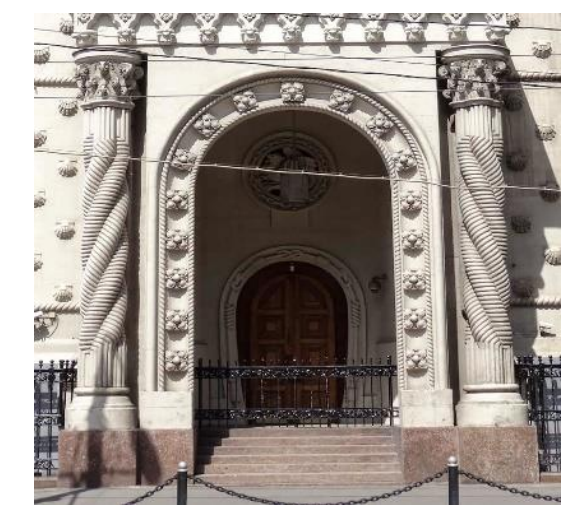

Figure 2 - The helical poles of Morozov's private residence, Moscow. The building was built in 1895-1899, arch. V. Mazyrin

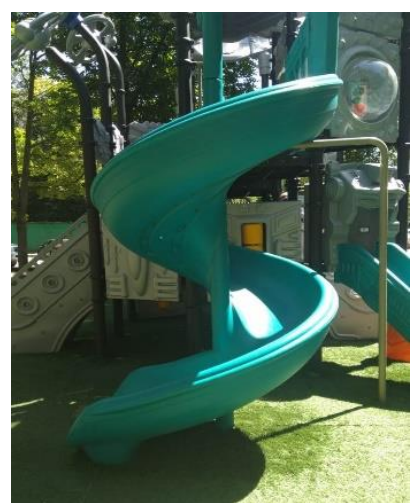

Figure 3 - Child slide

\subsubsection{Helical surfaces of variable pitch}

The helical surfaces of variable pitch can be seen in the thread of various types, in the forms of screw conveyors and worm presses, where relatively smooth changes in the pitch of the screw are usually made.

\subsection{Spiral surfaces}

The helical motion of this line forms a spiral surface with an arbitrary rigid curve in the planes of a pencil with a point moving along a conical spiral. A spiral surface with a straight generatrix in the planes of a pencil is formed by the helical motion of a straight line intersecting the axis of rotation at a constant angle. The other end of the straight line moves along the conical spiral. All points of the straight generatrixes will form the conic spirals. As an example of application of spiral surface with straight generatrixes in the planes of a pencil one can take the projects of houses "The Stairscrapers" designed by the architectural Bureau "Nabito Arquitecture". They became one of the finalists of the contest "Total Housing: Apartments 2010" that was held in New York (Fig. 4 [12]). 


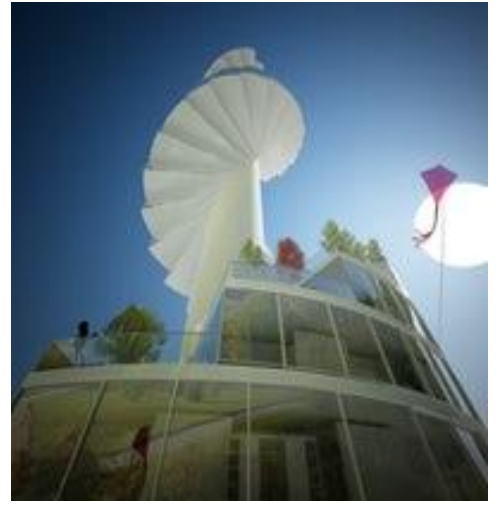

Figure 4 - The Stairscraper

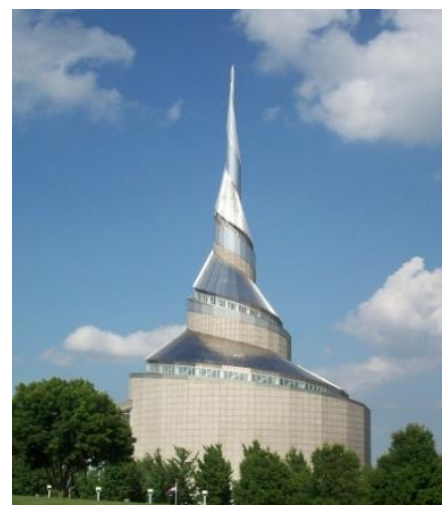

Figure 5 - Spiral-shaped roof

\subsection{Spiral-shaped surfaces}

Spiral-shaped surfaces (Fig. 5) are externally similar to spiral surfaces, but they cannot be assigned to one class since spiral surfaces have only a spiral on a circular cone as a directrix curve but a generatrix curve in the process of movement along the conical spiral curve does not change its shape and orientation. One can take any spiral on any surface as a directrix curve of spiral-shaped surface. In a paper [12], some spiral-shaped skyscrapers are described. Their forms with certain assumptions can be attributed to spiral-shaped surfaces. These are Strata Tower (Abu Dabi, architect Hani Rashid, Lise A. Couture, 2011), Fog Tower (Atacama, architect A. Fernandez, S. Ortega, 2008) and others.

\subsection{Helix-shaped surfaces}

Helix-shaped surfaces form a separate class of surfaces. In the special literature, designers often confuse the definitions of helical, helix-shaped, and spiral surfaces. The helix-shaped surfaces include surfaces formed by generatrix curves which in addition to a simple helical motion relative to the helical axis make any additional movement or deform according to a certain law. The trajectories of the points of the generatrix curve under helix-shaped motion will not be cylindrical helical lines. Helix-shaped surfaces at a certain selection of geometric parameters will degenerate into helical surfaces. 19 helix-shaped surfaces are represented in the encyclopedia [1] but descriptions of real structures are not found in available technical literature.

\subsection{Cyclic surfaces}

Cyclic surfaces are formed by circles of constant or variable radius in the process of their arbitrary movement in space [14]. These surfaces are mainly used in structures of machines of various purposes, in spiral chambers of refrigeration units, in high-pressure units, as fragments of attractions in sport-and-entertainment centers [3]. They can be seen in the form of spiral chambers of hydroelectric turbines. Among the huge number of cyclic surfaces offered by geometricians, only tubular surfaces and surfaces of revolution are used in the building industry and architecture.

An equation of a cyclic surface in a vector form is

$$
\boldsymbol{r}=\boldsymbol{r}(u, v)=\boldsymbol{\rho}(u)+R(u) \boldsymbol{e}(u, v),
$$

where $\boldsymbol{r}(u, v)$ is the radius-vector of a cyclic surface; $\boldsymbol{\rho}(u)$ is the radius-vector of a directrix curve; $R(u)$ is the law of changing of a radius of the generatrix circles; $\boldsymbol{e}(u, v)$ is a vector-function of the circle of the unit radius in the plane of the generatrix circle.

\subsubsection{Normal cyclic surfaces}

\subsubsection{Tubular surfaces}

Tubular spiral-shaped and helix-shaped surfaces are widely used in designing descents in children attractions (Fig. 6). As a form of a launching chute in an attraction, it may be recommend- 
ed to take a tubular surface on sphere or a tubular loxodrome [3]. Sometimes a tubular surface with an arbitrary line of centers is used as an exotic design of the whole building [3]. In a book [3], 17 types of tubular surfaces are proposed for integration.

\section{Circular torus}

Structures in the form of circular torus or its fragments are used much rarer than other surfaces of revolution. But architects know about this surface and sometimes use it in very original projects. The Ark project (Bioclimatic building with an autonomous life support system) was developed taking into account the Disaster Architecture program of the International Union of Architects and was nominated for the World Architecture Festival - 2010, received a third degree diploma based on the results of the First International Festival of Innovative Technologies in Architecture and Construction - 2010 " held in Moscow in the nomination" Conceptual Projects ".

There are some projects on using circular torus as a base surface for design of closed twisted box-shaped surfaces [15].

\subsection{Minimal surfaces}

Catenoid and right helicoid belong to the class of minimal surfaces. However, they are also surfaces of revolution and ruled surfaces of negative Gaussian curvature, respectively. In addition to them, only Schwartz minimal surfaces have been used in architecture. Information about the remaining minimal surfaces can be taken from the encyclopedia [1] and in [16, 17].

\subsubsection{Schwartz surface}

Having used several of the same type surfaces Schwartz, one can build embedded triply periodic minimal surfaces. A basic sell of Schwartz surface is disposed into the regular cube with the holes in all faces of the cube and has cubic symmetry. This fact is now widely used in architecture. For example, the Olympic Stadium in Munich (1972) was created with using minimal surfaces close to the Schwartz surface.

\subsection{One-sided surfaces}

One-sided and two-sided surfaces are two types of surfaces differing in the way of their disposition in the space. In the encyclopedia [1], 5 one-sided surfaces are shown and only models of a Mobius strip have found the application in architecture of small forms.

\subsubsection{Mobius strip (Moebius band)}

The strip twisted ones is called a Möbius strip, or a Moebius band. In contrast to its model, a Mobius strip has no thickness. Near the Museum of science and technology in Washington, steel model of the Mobius strip rotates on a pedestal. There is a sculpture "Mobius strip" in Ekaterinburg near the business center (Fig. 8), in Moscow and in other cities.

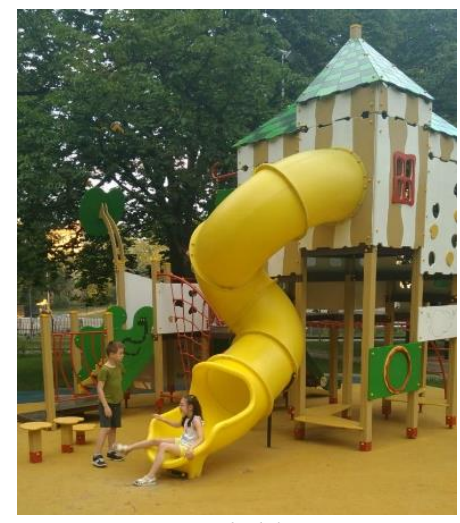

Figure 6 - Child attraction

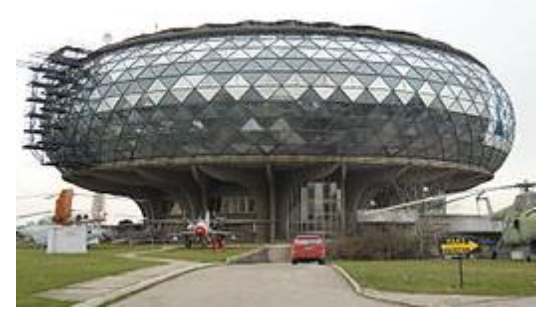

Figure 7 - The museum of aeronautics, Belgrade, Serbia. [https://ru.wikipedia.org]

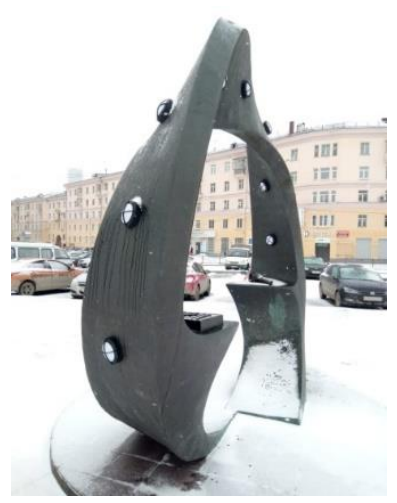

Figure 8 - "Mobius strip", Ekaterinburg, $R F$ 


\subsubsection{The Klein surface}

The German mathematician Felix Klein first described the Klein surface in 1882. It may have been originally named the Kleinsche Fläche ("Klein surface") and then misinterpreted as Kleinsche Flasche ("Klein bottle"). The Klein bottle has no boundary. Immersed Klein bottles are presented in the Science Museum in London. Designers and students like to make a wire mesh of a Klein bottle. McBride Charles Ryan gave the Klein bottle house unique shape in order to preserve the Australian landscape in which it is so snugly nestled*.

\subsubsection{The Boy surface}

The Boy surface is named after Werner Boy, who constructed this surface, which is an immersion of the real projective plane in Euclidean 3-space, in 1901 in his thesis. The model of the Boy surface in front of the Institute's library building has 3-fold rotational symmetry and minimizes the Willmore functional which measures elastic energy. On January 28th, 1991, it was installed at the MFO as a gift of Mercedes-Benz. Many models of the Boy surfaces were placed in different gardens.

\subsection{Surfaces of umbrella type}

A cyclic symmetrical spatial structure formed from several identical elements is called an umbrella dome. Curves obtained as a result of the intersection of their middle surfaces are the generatrixes of any dome-shaped surface of revolution.

The cyclic symmetrical surfaces consisting of several identical elements are called surfaces of umbrella type. But unlike an umbrella surface, the whole surface of umbrella type and all surfaces of the identical elements are determined by one and the same parametric equations

18 names of umbrella type surfaces [1,3] are known. Unfortunately, in literature on architecture, they do not indicate the method of formation of surfaces and do not give their analytical equations and that is why it is difficult to classify these two types of surfaces. For instance, architect Marchand J.R. used the shell for covering of the restaurant near "La Concha hotel" (Fig. 9). This form is very similar to the umbrella-type surface with astroid lines of level formed by biquadrate parabolas.

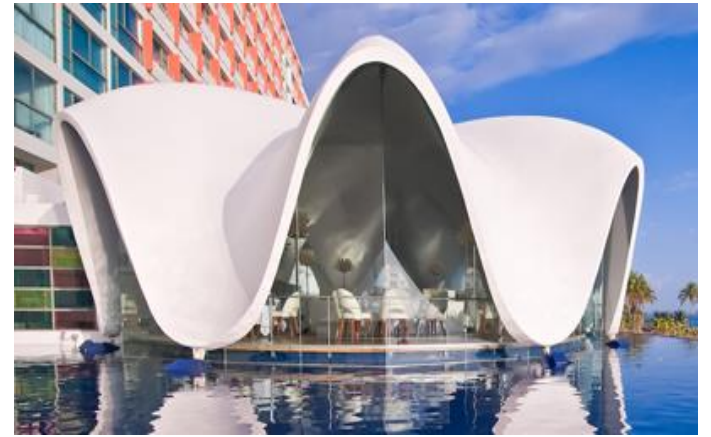

Figure 9 - Restaurant near the "La Concha hotel", San Juan, Puerto Rico [http://www. architecturaldigest.com/homes/hotels/2009]

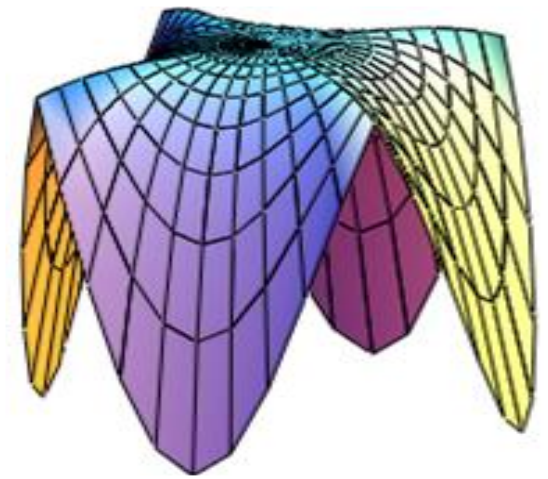

Figure 10 - Umbrella-type surface

This surface was proposed in $[1,18]$ (Fig. 10). Its parametrical equations are

$$
x=x(t, u)=a u^{1 / 4} \cos ^{3} t, \quad y=y(t, u)=a u^{1 / 4} \sin ^{3} t, \quad z=z(u)=H(1-u),
$$

where $u$ is a dimensionless parameter; $0 \leq u \leq 1 ; 0 \leq t \leq 2 \pi ; H$ is the rise of the surface.

\footnotetext{
* https://inhabitat.com/gorgeous-origami-esque-klein-bottle-house-nestles-into-australias-landscape/ 
Apparently, surfaces of umbrella type $[19,20]$ are little known to engineers and architects in contrast to umbrella surfaces [21].

\subsection{The second order surfaces}

The second order surfaces are defined by algebraic equations of the second order relatively to the Cartesian coordinates. The second order surfaces are called also quadratic surfaces or quadrics. 17 quadratic surfaces are known.

The most of quadratic surfaces are included in other classes of surfaces and were presented in other works of the authors. These are cylindrical surface of revolution, elliptic cylinder, parabolic cylinder, conical surface of revolution [22], ellipsoid of revolution, one-sheet hyperboloid, and paraboloid of revolution [11]. Hyperbolic paraboloids (hypars) are very well known roof structures $[22,23]$.

Consider some more second-order surfaces used in real structures.

\subsubsection{Three-axial ellipsoid}

The application of this surface is illustrated by the example of the Wedding Palace, which is located at the top of the two-level "Picturesque bridge" (Fig. 11), Moscow. One level is provided for cars, the other for the subway. The capsule is made of iron and glass and is $34 \mathrm{~m}$ long, $23 \mathrm{~m}$ wide, and weighing 650 tons. It is suspended at a hundredmeter height. Its Grand opening took place on December 27 in 2007. For the determination of stress-strain state of threeaxial ellipsoid by FEM one can use a method offered in a paper [24].

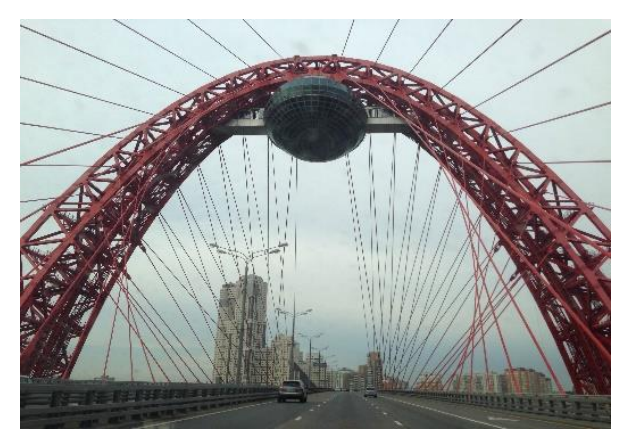

Figure 11 - Restaurant and wedding Palace, Picturesque Bridge, Moscow

\subsubsection{Elliptic paraboloid}

Elliptical paraboloid can be given by parametrical equations:

$$
x=x, y=y, z=z(x, y)=x^{2} /(2 p)+y^{2} /(2 q) .
$$

These parametrical equations show that elliptic paraboloid is a surface of translation and formed by movement of one main parabola along another [10]. So, a sport hall on an elliptic ground plan of $96 \times 64 \mathrm{~m}$ in Hungary was covered by a reticulated tubular shell structure having the form of an elliptic paraboloid.

A reinforced concrete dome covering of the Smithfield Poultry Market, architect T.P. Bennett and Son, engineer Ove Arup, in London (UK) was built in 1961-1963 on the spot of the old market building brnt in 1958. A new building was designed in the form of an elliptic paraboloid with the dimension of $68.6 \times 38.12 \mathrm{~m}$ in plan, $9.1 \mathrm{~m}$ high, a shell thickness is $7.5 \mathrm{~cm}$, a shell thickness in corners is $20 \mathrm{~cm}$. A middle surface of the shell is defined by an equation $z=$ $\left(x / r_{x}\right)^{2}+\left(y / r_{y}\right)^{2}$ (Fig 12). Having been inside, the visitors wonder and express an admiration with triumph of technical idea [25]. At the moment of erection, it was the largest thin-walled

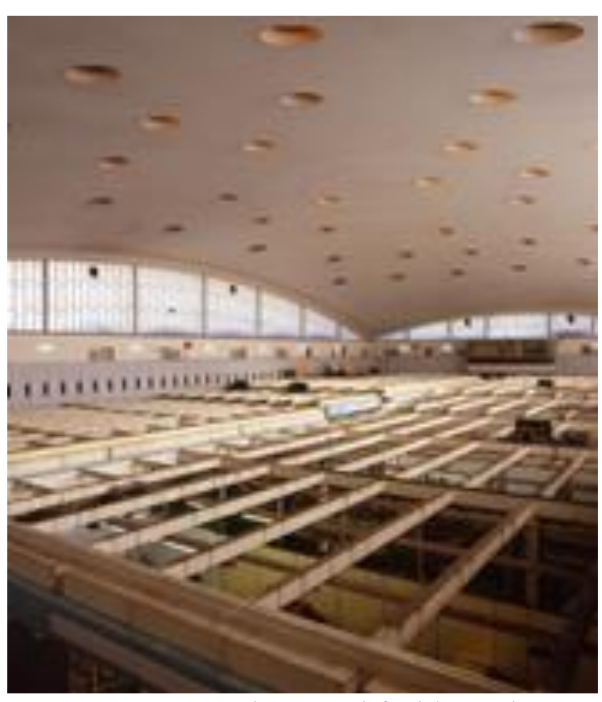

Figure 12 - The Smithfield Poultry Market, London reinforced concrete shell. 


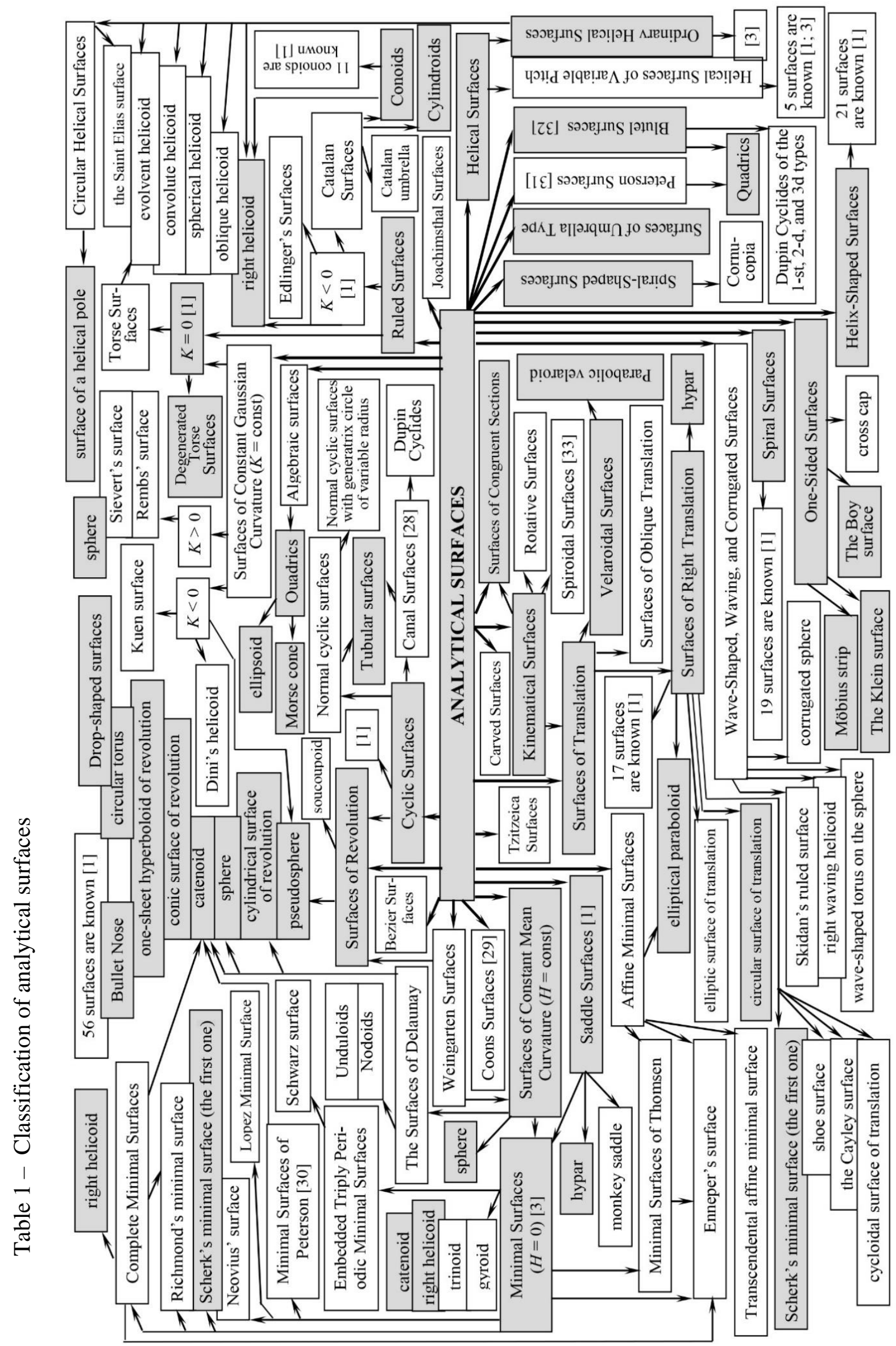




\section{Proposals for discussion}

The study shows that out of the 600 analytical surfaces listed in the encyclopedia [1] only 42 surfaces have been used in architecture and building in the World. Previously, a similar study was conducted on the example of Moscow [5] and it was found that only 18 analytical surfaces were used in Moscow. The materials of the research suggest that geometricians are significantly ahead of the needs of architects and builders, or architects have not yet mastered the entire set of analytical surfaces proposed by geometricians, or architects consider the most analytical surfaces unsuitable for their creative concepts. May be they prefer analytically undefined surfaces. Often the shape of surface is designed by architects and geometricians make later its mathematical description.

With the advent of variation difference method, finite element method, and other numerical methods, engineers received a powerful tool for the expanded using of thin-walled large-span shells and other types of structures of various shapes [26,27].

\section{Conclusion}

In works $[5,8-11,20,22]$, the authors have begun the researches of a degree of application of methods of analytical and differential geometry of surfaces for shape finding methods of thinwalled shells. Now for the first time, a classification of analytical surfaces in the obvious graphic form was offered and it was shown that only not considerable part of the known analytical surfaces was used for design of building shell structures. This situation can be corrected by introduction of geometric researches of surfaces and advanced analytical and numerical methods of strength analysis into a design practice. So, owing to the presented investigations, the builders and designers have a good opportunity to choose new surface of attractive shape with given geometrical parameters but unknown to other designers. For clarity, a classification of analytical surfaces is given in a tabular form (Table 1). The surfaces, found the application in architecture and building, are darkened. The surfaces, that can be used in architecture and building, are shown in Table 1 in open frames. The materials of the paper can help to choose a proper criterion of optimality for a shell and to use optimal shell design.

\section{Acknowledgments}

The publication has been prepared with the support of the "RUDN University Program 5$100 "$.

\section{REFERENCES}

1. Krivoshapko S.N., Ivanov V.N. Encyclopaedia of Analytical Surfaces. Springer International Publishing Switzerland. 2015. 752 p. DOI 10.1007/978-3-319-11773-7_13

2. Grinko E.A. Classification of analytical surfaces as applied to parametrical architecture and machine buildingю RUDN Journal of Engineering Researches. 2018. 19(4). Pp. 438-456 http://dx.doi.org/10.22363/2312-8143-201819-4-438-456 (rus)

3. Krivoshapko S.N., Mamieva I.A. Analytical Surfaces in Architecture of Buildings Structures and Products: Monography. Moscow: LIBROCOM Publ, 2018. 328 p. (rus)

4. Podgorniy A.L., Grinko E.A., Solovey N.A. On research of new surface forms as applied to structures of diverse purpose. RUDN Journal of Engineering Researches. 2013. 1. Pp 140-145. http://journals.rudn.ru/engineeringresearches/article/view/4746/4200 (rus)

5. Mamieva I.A., Razin A.D. Parametrical architecture in Moscow. Architecture and construction of Russia. 2014. 6. Pp. 25-29. https://elibrary.ru/download/elibrary_21614483_57957742.pdf (rus)

6. Esipova A.A., Aganova A.Yu. Parametrical architecture. Leading style in architecture of future. Molodyozhn. Nauchn. Forum: Tehnich. i Matem. Nauki: in Elektr. Sb. st. po Mat. XVII Mezhdun. Stud. Nauchno-Prakt. Konf. 10(17) url: https://nauchforum.ru/studconf/tech/xvii/4585(rus)

7. Schnabel M.A. Parametric Designing in Architecture. In: Dong A., Moere A.V., Gero J.S. (eds) Computer-Aided Architectural Design Futures (CAADFutures). Springer, Dordrecht. 2007. pp 237-250 https://doi.org/10.1007/978-1-4020-6528-6_18 
8. Mamieva I.A., Razin A.D. Pyramids in modern architecture. Industrial and Civil Engineering. 2018. 5. Pp 40-45. https://elibrary.ru/download/elibrary_30548522_75575692.pdf(rus)

9. Mamieva I.A., Razin A.D. Landmark spatial structures in the form of conic surfaces. Promyshlennoe $i$ Gra$\begin{array}{lllllll}\text { zhdanskoe Stroitelstvo [Industrial and Civil Engineering]. } & 2017 . & 10 . & \mathrm{Pp} & 5-11 .\end{array}$ https://elibrary.ru/download/elibrary_30548522_84995095.pdf (rus)

10. Krivoshapko S.N., Gbaguidi Aïssè G.L. Geometry, static, vibration and buckling analysis and applications to thin elliptic paraboloid shells. The Open Construction and Building Technology Journal. 2016. 10(1). Pp 576-602. DOI: $10.2174 / 1874836801610010576$

11. Gbaguidi Aïssè G.L. Influence of the geometrical researches of surfaces of revolution and translation surfaces on design of unique structures. Structural Mechanics of Engineering Constructions and Buildings. 2019. 15(4). Pp. 308-314 DOI 10.22363/1815-5235-2019-15-4-308-314

12. Krasic Sonja. Geometrijske Površi u Arhitekturi. Gradevinsko-arhitektonski fakultet Univerzitet u Nišu. 2012. 238 p. ISBN 978-86-88601-02-3 236 COBISS.SR-ID 190337036 M42 (serbian)

13. Rigoberto E.M. Morales; Eugênio S. Rosa. Modeling of free surface flow in a helical channel with finite pitch. J. Braz. Soc. Mech. Sci. \& Eng. 2007. 29(4) Rio de Janeiro. http://dx.doi.org/10.1590/S167858782007000400002

14. Saveliev Yu.A. Cyclic surfaces. Surfaces with similar sections. Yekaterinburg:UGUPS: 2008. 54 p. (rus)

15. Ivanov V.N., Romanova V.A. Constructive Forms of Spatial Structures (Visualization of Surfaces in MathCad, AutoCad). Moscow: ASV Publ., 2016. 412 p. ISBN 987-5-4323-0179-6(rus)

16. Gray A. Modern Differential Geometry of Curves and Surfaces with Mathematica: $2^{\text {nd }}$ ed. Boca Raton, FL: CRC Press. 1998. 1053 p. ISBN 9781584884484 - CAT\# C4487

17. Goziridze A.F. Model tests of reinforced concrete shells in the form of soap films. Stroit. Meh. Prostranstv. Konstruktziy. Tbilisi. 1974. Vol. 2. Pp. 34-37. (rus)

18. Hyeng Ch. A. Bock, Krivoshapko S.N. Umbrella-Type Surfaces in Architecture of Spatial Structures. IOSR Journal of Engineering. 2013. 3(3). Pp. 43-53 DOI: 10.9790/3021-03334353

19. Ariarskyi O.E., Shagalova I.V., Kravchenko T.V., Kulakova E.A. Umbrella surfaces morphology and their application in the architecture and design. The Work of TDATU. 2011. 4(49). Pp. 178-190. (rus)

20. Krivoshapko S.N., Mamieva I.A. Umbrella surfaces and umbrella-typed surfaces in architecture. Promyshlennoe $i$ Grazhdanskoe Stroitelstvo [Industrial and Civil Engineering]. 2011. 7(1). Pp. 27-31. https://elibrary.ru/item.asp?id=16522830 (rus)

21. Kadam S.S., Gandhe G.R., Tupe D.H. Advanced Modeling and Analysis of Plate and Inverted Umbrella Roof Shell Using ANSYS. IJSR. 2019. 8(2). Pp. 538-542. www.ijsr.net

22. Mamieva I.A. Influence of the geometrical researches of ruled surfaces on design of unique structures. Structural Mechanics of Engineering Constructions and Buildings. 2019. 15(4). Pp. 299-307. DOI 10.22363/18155235-2019-15-4-299-307

23. Kadam S.S., Gandhe G.R., Tupe D.H. Finite Element Analysis Of Hyperbolic Paraboloid Shell By Using ANSYS. IRJET. 2017. 04(02). Pp. 99-104. www.irjet.net

24. Klochkov Yu.V., Nikolaev A.P., Kiseleva T.A., Marchenko S.S. Comparative analysis of the results of finite element calculations based on an ellipsoidal shell. Journal of Machinery Manufacture and Reliability. 2016. 45(4). Pp 328-336

25. Forty Andrian. Building of the Month. The Twentieth Century Society. 2012. http://www.c20society.org.uk/docs/building/poultry.html

26. Maan H. Jawad. Design of Plate \& Shell Structures. ASME Press. 2004. 476 p. https://www.wiley.com/enam/exportProduct/pdf/9781860583322

27. Adriaenssens S., Block P., Veenendaal D., Williams C. (editor). Shell Structures for Architecture: Form Finding and Optimization. Routledge London. 2014. 340 p. https://block.arch.ethz.ch/brg/

publication/shells-for-architecture-form-finding-and-structural-optimization

28. Soliman M.A., Mahmoud W.M., Solouma E.M., Bary M. The new study of some characterization of canal surfaces with Weingarten and linear Weingarten types according to Bishop frame. J of the Egyptian Mathematical Society. 2019. 27:26. https://doi.org/10.1186/s42787-019-0032-y

29. Ivanov V.N. Architectural compositions on the base of the Coons surfaces. Structural Mechanics of Engineering Constructions and Buildings. 2007. 4. Pp. 5-10 https://elibrary.ru/download/elibrary_11532259_27974679.pdf (rus)

30. Korolev E.A., Fomina T.N. Peterson minimal surfaces. Ukrain. Geom. Sb. 1979. 22. Pp. 92-96. (rus)

31. Mlodzievskiy B.K. On surfaces dealing with Peterson surfaces. Matem. Sb. 1900. 21. Pp. 450-460. (rus)

32. Degen W. Die zweiflachen Blutelschen Kegelschnittflächen. Manuscr. Math. 1986. 55(1). Pp 9-38.

33. Krivoshapko S.N., Shambina S.L. The researches and visualization of rotative and spiroidal surfaces. Prikladna Geometriya ta Injenerna Grafika. Prazi TDATU. 2011. 4(49). Pp. 33-41. (rus) 


\section{СПИСОК ЛИТЕРАТУРЫ}

1. Krivoshapko S.N., Ivanov V.N. Encyclopaedia of Analytical Surfaces. Springer International Publishing Switzerland. 2015. 752 p. DOI 10.1007/978-3-319-11773-7_13

2. Гринько Е.А. Классификация аналитических поверхностей применительно к параметрической архитектуре и машиностроению// Вестник Российского университета дружбы народов. Серия: Инженерные исследования. 2018. Том 19, № 4. С. 438-456. http://dx.doi.org/10.22363/2312-8143-2018-19-4-438-4563.

3. Кривошапко С.Н., Мамиева И.А. Аналитические поверхности в архитектуре зданий, конструкций и изделий: Монография. М.: Книжный дом «ЛИБРОКОМ», 2018. - 328 с.

4. Подгорный А.Л., Гринько Е.А., Соловей Н.А. Исследование новых форм поверхностей применительно к конструкциям различного назначения// Вестник Российского университета дружбы народов. Инженерные исследования. 2013. № 1. С. 140-145. http://journals.rudn.ru/engineering-researches/article/view/4746/4200

5. Мамиева И.А., Разин А.Д. Параметрическая архитектура в Москве// Архитектура и строительство России. 2014. № 6. С. 24-29 https://elibrary.ru/download/elibrary_21614483_57957742.pdf

6. Есипова А.А., Аганова А.Ю. Параметрическая архитектура - ведущий стиль в архитектуре будущего // Молодежный научный форум: технические и математические науки: Электр. сб. ст. по мат. XVII Междунар. студ. науч.-практ. конф., № 10(17). url: https://nauchforum.ru/archive/mnf_tech/10(17).pdf (дата обращения: 30.03.2019)

7. Schnabel M.A. Parametric Designing in Architecture// In: Dong A., Moere A.V., Gero J.S. (eds) Computer-Aided Architectural Design Futures (CAADFutures). Springer, Dordrecht. 2007. Pp 237-250 https://doi.org/10.1007/978-1-4020-6528-6_18

8. Мамиева И.А., Разин А.Д. Пирамиды в современной архитектуре// Промышленное и гражданское строительство. С. 40-45. https://elibrary.ru/download/elibrary_30548522_75575692.pdf

9. Мамиева И.А., Разин А.Д. Знаковые пространственные сооружения в форме конических поверхностей // Промышленное и гражданское строительство. 2017. № 10. С. 5-11.

https://elibrary.ru/download/elibrary_30548522_84995095.pdf

10. Krivoshapko S.N., Gbaguidi Aïssè G.L. Geometry, static, vibration and buckling analysis and applications to thin elliptic paraboloid shells// The Open Construction and Building Technology Journal. 2016. 10(1). Pp 576-602. DOI: $10.2174 / 1874836801610010576$

11. Gbaguidi Aïssè G.L. Influence of the geometrical researches of surfaces of revolution and translation surfaces on design of unique structures// Строительная механика инженерных конструкций и сооружений. 2019. 15(4). Pp. 308-314 DOI 10.22363/1815-5235-2019-15-4-308-314

12. Krasic Sonja. Geometrijske Površi u Arhitekturi. Gradevinsko-arhitektonski fakultet Univerzitet u Nišu. 2012. 238 p. ISBN 978-86-88601-02-3 236 COBISS.SR-ID 190337036 M42

13. Rigoberto E.M. Morales; Eugênio S. Rosa. Modeling of free surface flow in a helical channel with finite pitch// J. Braz. Soc. Mech. Sci. \& Eng. 2007. 29(4) Rio de Janeiro. http://dx.doi.org/10.1590/S167858782007000400002

14. Saveliev Yu.A. Cyclic surfaces. Surfaces with similar sections. Yekaterinburg:UGUPS: 2008. 54 p.

15. Иванов В.Н., Романова В.А. Конструкционные формы пространственных конструкций. Визуализация поверхностей в системах MathCad, AutoCad. М.: Изд-во ACB, 2016. 412 с. ISBN 987-5-4323-0179-6

16. Gray A. Modern Differential Geometry of Curves and Surfaces with Mathematica: $2^{\text {nd }}$ ed. Boca Raton, FL: CRC Press. 1998. 1053 p. ISBN 9781584884484 - CAT\# C4487

17. Гоциридзе А.Ф. Экспериментальные исследования железобетонных оболочек в форме мыльных рленок// Строительная механика пространств. конструкций. Тбилиси, 1974. Vol. 2. C. 34-37.

18. Hyeng Ch. A. Bock, Krivoshapko S.N. Umbrella-Type Surfaces in Architecture of Spatial Structures// IOSR Journal of Engineering. 2013. 3(3). Pp. 43-53 DOI: 10.9790/3021-03334353

19. Ариарский О.Е., Шагалова И.В., Кравченко Т.В., Кулакова Е.А. Морфология зонтичных поверхностей и их применение в архитектуре и проектировании// Труды ТДАТУ. 2011. 4(49). С. 178-190.

20. Кривошапко С.Н., Мамиева И.А. Зонтичные поверхности и поверхности зонтичного типа в архитектуре // Промышленное и гражданское строительство. 2011. № 7 (1). https://elibrary.ru/item.asp?id=16522830

21. Kadam S.S., Gandhe G.R., Tupe D.H. Advanced Modeling and Analysis of Plate and Inverted Umbrella Roof Shell Using ANSYS// IJSR. 2019. 8(2). Pp. 538-542. www.ijsr.net

22. Mamieva I.A. Influence of the geometrical researches of ruled surfaces on design of unique structures// Строительная механика инженерных конструкций и сооружений. 2019. 15(4). Pp. 299-307. DOI 10.22363/18155235-2019-15-4-299-307

23. Kadam S.S., Gandhe G.R., Tupe D.H. Finite Element Analysis Of Hyperbolic Paraboloid Shell By Using ANSYS// IRJET. 2017. 04(02). Pp. 99-104. www.irjet.net

24. Klochkov Yu.V., Nikolaev A.P., Kiseleva T.A., Marchenko S.S. Comparative analysis of the results of finite element calculations based on an ellipsoidal shell// Journal of Machinery Manufacture and Reliability. 2016. 45(4). Pp 328-336. 
25. Forty Andrian. Building of the Month. The Twentieth Century Society. 2012. http://www.c20society.org.uk/docs/building/poultry.html

26. Maan H. Jawad. Design of Plate \& Shell Structures. ASME Press. 2004. 476 p. https://www.wiley.com/enam/exportProduct/pdf/9781860583322

27. Adriaenssens S., Block P., Veenendaal D., Williams C. (editor). Shell Structures for Architecture: Form Finding and Optimization. Routledge London. 2014. 340 p. https://block.arch.ethz.ch/brg/

publication/shells-for-architecture-form-finding-and-structural-optimization

28. Soliman M.A., Mahmoud W.M., Solouma E.M., Bary M. The new study of some characterization of canal surfaces with Weingarten and linear Weingarten types according to Bishop frame// J of the Egyptian Mathematical Society. 2019. 27:26. https://doi.org/10.1186/s42787-019-0032-y

29. Иванов В.Н. Архитектурные композиции на основе поверхностей Кунса// Строительная механика

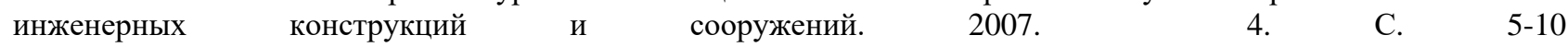
https://elibrary.ru/download/elibrary_11532259_27974679.pdf

30. Королев Е.А., Фомина Т.Н. Минимальные поверхности Петерсона// Украин. геометр. сборник. 1979. 22. C. $92-96$.

31. Млодзиевский Б.К. О поверхностях, связанных с поверхностями Петерсона// Математический сборник. 1900. 21. С. 450-460

32. Degen W. Die zweiflachen Blutelschen Kegelschnittflächen// Manuscr. Math. 1986. 55(1). Pp 9-38.

33. Кривошапко С.Н., Шамбина С.Л. Исследование и визуализация ротативных и спироидальных поверхностей// Прикладна геометрія та інженерна графіка. Праці Таврійський державний агротехнологічний університет. Вип. 4, т. 49. Мелітополь: ТДАТУ, 2011. С. 33-41.

\section{Information about authors:}

\section{Mamieva Iraida A.}

Peoples' Friendship University of Russia (RUDN University), Moscow, Russia, leading specialist of the Engineering Academy of RUDN University

E-mail: i_mamieva@mail.ru

\section{Gbaguidi-Aisse Gerard L.}

Laboratoire d'énergétique et de mécanique appliquées (LEMA) Ecole Polytechnique d'Abomey-Calavi/ Univ. d'Abomey-Calavi BP 2009 Cotonou, République du Bénin,

DSc, Professor, Conseiller Technique Charge des Infrastructures, des Equipements Universitaires

E-mail: gbaguidi.gerard@yahoo.fr

\section{Информация об авторах:}

\section{Мамиева Ираида Ахсарбеговна}

Российский университет дружбы народов, Москва, Российская Федерация, ведущий специалист Инженерной академии РУДН,

E-mail: i_mamieva@mail.ru

\section{Гбагуиди Айссе Жерар Леопольд}

Университет Абомей-Калави, 02 ВР 244 Котону, Республика Бенин, д-р техн. наук, профессор, советник министра образования республики Бенин, E-mail: gbaguidi.gerard@yahoo.fr 